\title{
Study on the National Image Transmission in International Cultural Trade
}

\author{
Gong Yuhua ${ }^{1, *}$ \\ ${ }^{1}$ School of Economics and Management, Communication University of China, Chaoyang, Beijing, China \\ *Email: rmrbgyh@126.com
}

\begin{abstract}
As China rises peacefully, the curiosity of the outside world about China is increasing day by day, meanwhile the misunderstandings and frictions are staged from time to time. In this brand-new world pattern, the shaping of China's national image and the output of soft power seem to have a long way to go. In addition to the actions of Chinese government, folk cultural exchange and communication is very important. Among them, we should pay attention to the important role played by international cultural trade. Good cultural trade helps to promote Chinese culture going global, in which way helps to establish a good image of China. In recent years, enterprises are becoming the main body of cultural outreach. While doing business with foreign customers, they spread Chinese values and spirit and enhance the understanding of foreign governments and people about China.
\end{abstract}

Keywords: national image, Chinese culture going global, cultural trade

\section{INTRODUCTION}

As China's rise continues, curiosity about China is growing. In this new world pattern, China's public diplomacy and national image building and dissemination is more arduous. In retrospect, the image of China in the past was often too strong to be accepted: such as the frequent appearance of landmarks, the well-dressed social elites, the proud economic achievements, the scientific and technological breakthroughs.etc. These lofty themes can boost the confidence of the nation and portray a prosperous and civilized modern society. But at the same time, the onesided emphasis on scale or speed, is difficult to get the foreign people's respect and deep value recognition. We should know that once the spread of symbolic propaganda, it would lead to the dissemination of the target to the selflabel of the numb, doubt, and even antipathy. In that case, the spread of national image would be alienation the Chinese official discourse system into self-entertainment. How to overcome the awkwardness of trying too hard? From the perspective of "daily strengthening power", this paper tries to study on how to promote Chinese culture to go global through the power of international cultural trade in the context of global economic integration and in the pattern of "global village" intensified by the Internet, so as to facilitate the development of public diplomacy and the spread of national image.

According to the analysis of human history, national consciousness appears not only in political reports, but also in family daily life, sports broadcasting and popular culture. On the basis of tens of thousands of exporting movies, TV programs, books and magazines, the "text" established, although as a "foreign image", has become the daily life of the importing country, at where people will soon become accustomed to the image of these countries, and even into their way of thinking and behaving. In the words of Tomlinson, an American media scientist, "they will soon be normalized in the media life world of individuals." It can be seen that, unlike explicit ideological propaganda, such "daily cultural reinforcement" will silently convey the values of the exporting countries, reduce the confrontation of the foreign audiences, and achieve twice the result with half the effort in building a good national image. [1]

\section{BACKGROUND}

In recent years, in the process of spreading national image of China, Chinese culture going global has become a clarion call.

Going global was firstly proposed as a strategy in the economic field in China, and its roots date back to the 14th national congress of the communist party of China. In October of 2000, the fifth plenary session of the 15th CPC central committee made it clear for the first time that the strategy of going global should be implemented. In July of 2002, Sun jiazheng, then minister of culture, pointed out for the first time that culture should be going global in the cultural field too. Since then, the strategy of Chinese culture going global has gradually become a national strategy, and required in the successive development programs as actively exploring the international cultural market, cultivating export-oriented backbone cultural enterprises, and promoting Chinese culture going global to the world. [2]

Cultural exchanges, cultural communication and cultural trade have jointly supported the pattern of Chinese culture going global. However, a review of history reveals that more than a decade has passed and there are still many 
problems in the development of China's international cultural trade.

\subsection{Strength base}

It has been 20 years since the concept of "cultural industry" first appeared in China's national documents in 2000. Combing the formation of cultural industry, there are the following aspects. One is the transformation of public institutions into enterprises, such as Beijing Performing Arts Group, Beijing Puppet Theater, Children's Art Theater and other performing arts departments, as well as the Phoenix Publishing Group, Beijing Publishing Group and other publishing units. These units became state-owned cultural enterprises after restructuring, and now dominate the cultural industry market. After 2000, with the entry of social capital into the cultural field, a large number of private cultural enterprises emerged. In addition, there are different levels of foreign investment in individual sectors, but the degree of openness is still small. Above three kinds of cultural enterprises, respectively have difficulties of themselves to solve.

Firstly, many state-owned cultural enterprises, both the central and the local enterprises, have the idea of waiting for help, relying on the state and asking for resources in their deep heart, which makes it difficult for them to adapt to the open market competition for a very long time. Their fixed thinking habit makes them turn to the government whenever there is a problem. Although it has been transformed into an enterprise, it lags behind in thinking and business model.

Secondly, for private-owned cultural enterprises, the reason why they did not go global before is lack of ability. And on the other hand, there is a very important factor is that the domestic market competition is not saturated, and many enterprises do not have the motivation to go out. The development of international cultural trade is faced with greater risks, including risks in system, operation, personnel and exchange rate. Only when the domestic market has become saturated, and the domestic market competition pressure is huge, the owner of the private cultural enterprises would look for comparative advantages in the international market. At present, the structural contradiction between supply and demand is still relatively large, and the demand of domestic consumers has not been fully met. From the point of view of supply, too much ineffective supply cannot become economic value in the market. The total output seems large, but there is still a contradiction between supply and demand.

Thirdly, foreign cultural enterprises in China, however, are still subject to a lot of restrictions. For example, The Pretty Woman Media Group is a collection of television transmission, film and television shooting, speaker production and distribution, original animation and derivative products production. As one of the Chinese cultural media enterprises, it committed to go global. In 2009 it managed to buy ICN television network in the United States. The Chinese people is shocked that a Chinese company can buy a television network in the
United States, because it is impossible for a foreign company to do that in China. [3]

In one word, on the whole, the China's cultural enterprises are still generally weak and undeveloped.

\subsection{Policy environment}

For a long time, the Chinese government has given away a large number of Chinese classic books to foreign people and exported its best performances to foreign countries for free, but it proved that this action does not work, for the foreigners still know little about Chinese culture. Because of the language and cultural barriers, the local people merely contact with this Chinese books and performances, and the audience who come to the performances is turned out to be the Chinese people living there but not the local foreign people. In that case, the Chinese culture going global is often kept on the surface and without actual effect.

In general, the Chinese government attaches great importance to cultural exchange, rather than cultural trade. Therefore the proportion of China's foreign cultural exchanges is much greater than that of cultural trade. In the name of foreign cultural exchanges, the government has paid a lot of money every year. We can't say the money is wasted because of little economic benefits, for it is a part of the national plan which is needed to match the political and diplomatic needs. For it will also exert certain influence in foreign countries and help exchanges and overseas Chinese affairs. However, from the long perspective of developing, cultural exchange should not become the main body of Chinese culture going global. The cultural trade and the enterprises should play a more important role in the future in the Chinese culture going global strategy. With the development of the China's cultural enterprises, the government should better have a push to develop international cultural trade, and attach great importance to cultural trade.

\subsection{Market performance}

In recent years, China's international cultural trade has made some achievements. According to the statistics of UNESCO, China has become the third largest exporter of cultural products and services several years ago. [4] Meanwhile the unreasonable structure of the cultural industry has become increasingly obvious.

In fact, this contradiction in cultural industry has been a consensus: the production of cultural industry is at huge amount, but the supply of high-quality goods is insufficient to meet the customers' growing demand for cultural consumption. In that way, the cultural industry also needs to carry out a systematic supply-side reform, eliminating backward production capacity, facing the reality of higher and higher demands of the customers, meeting the needs of more and more detailed tastes, and 
adapting to the era of increasingly diverse cultural consumption.

In addition, through the comparison of Chinese and foreign cultural market, we can see that the market mechanism underdevelopment of China's cultural industry is the fatal cause of the inefficient going out. Because of different concepts, the cultural industry of the United States is based on the opinions of market theory, meaning that different opinions can be freely exchanged in the market, which resulting to the protection of its original cultural products. From the perspective of the property market, the corporate property rights of American cultural industry can flow freely. None of the American big multinational media groups has grown successful without dozens of property deals. As we all know, there is no department of culture in the United States, and the policy towards culture is only reflected in the first amendment. The telecommunications act of 1996 can be regarded as the most authoritative regulation of this industry, which helps the development of this field. What is more, The United States federal telecommunications commission (FFC) has been in the state of broadcasting regulation of the media industry for decades, which guarantees the interests of investors. [5]Through comparison, we can see that China's cultural industry still has a lot to be improved in terms of market mechanism.

\subsection{Cultural communication}

The effect of the Chinese cultural communication is to spread the value and spirit of Chinese people, changing the misunderstanding about China. What is influence? Influence refers to the ability to influence others' attitude and behaviors in one's own way. Its essence is a kind of power, leading and changing the audience's cognition, tendency, opinion, attitude and decision. Fundamentally, it is an important study to understand the influence and formation process of cultural industry and how to transform cultural influence into a national deterrent and national attraction.

However, due to the low market share and developing cultural brands, the spring of China's international cultural trade is still in a difficult gestation.

\section{STRUCTURE}

In order to give full play to the role of cultural trade and promote the spread of China's national image, it is imperative to dilute the administrative power from government and fully activate the dominant power of cultural enterprises in the increasingly active international cultural trade environment.

In the past two years, Chinese companies have played a more important role in international cultural trade while there is still a lot of work to do.

\subsection{To build greater international cultural trade platform}

At present, China has built a number of international platforms such as the Beijing International Film Festival, the China (Guangzhou) International Documentary Festival, and the China Beijing International Cultural and Creative Industry Expo. Besides holding important activities in the country, China has made it happen outside of China. In 2014, for example, China held 65 Chinese film festivals in 44 foreign countries, showing 452 films. The establishment of these international platforms provides opportunities for the sale and business of Chinese cultural products.

Compared with doing business one by one, building of international cultural trade platforms is like ship building which is conducive to optimizing the allocation of resources, expanding the international marketing network, and promoting the entry of Chinese cultural products into the foreign countries. However, how to make these international cultural trade platforms stronger and bigger still requires considerable practice and exploration.

\subsection{To carry out mergers and acquisitions overseas}

None of the large multinational media and cultural groups in the US has grown up without many property rights acquisitions. For example, Murdoch's News Corporation started in Australia and purchased a number of companies including the British World News, the Sun, and the United States Fox. In the past few decades, it has experienced dozens of mergers and acquisitions before it is now of the super media predator. The liquidity of property rights is one of the basic conditions for enterprises to become larger and stronger, especially in the cultural industry. [6] Now, overseas acquisitions have been included in the development of the entire cultural industry chain. In addition, people should pay attention to the operations after acquisitions. For capital purchasing is the first step, later operations also require much more wisdom. Due to the different cultural backgrounds, market environments, and institutional mechanisms of China and foreign countries, if there is not a good plan after the merger and acquisition, the integration will be difficult in the later stages. Whether can business enterprise merger obtain success, corporate culture of fusion is essential.

\subsection{To innovate cooperation mechanisms and reduce cultural discounts}

Take "Zhen Huan Biography" as an example. In the past, Chinese film and television works exported overseas were mostly re-edited and packaged to suit the viewing habits and aesthetic tastes of foreign audiences. This is necessary, 
but another much more efficient production method maybe is Sino-foreign cooperation, which means international communication has been taken into consideration at the beginning of the film and television projects. Only the destination country audience identify with the way the core of China's value and Chinese culture showed, can the phenomenon of cultural discount be minimized. Practices in various countries have shown that selling cultural products to the foreigners is more effective than sending them for free. The role of cultural trade and investment is worth looking forward to finding out. Chinese culture must not only go out of China, but also go into the foreign country, and moisturize it into the daily life of foreigners. [7]

\subsection{To serve the cultural companies in more appropriate ways}

At present, although some private cultural companies have made a name for themselves abroad. After all, the total amount of successful cultural company is still small. This attempt is at beginning and in a state of healthy growth, and there may be greater progress in the future. Nowadays, from the central to the local, the governments are committed to exerting the synergy between the cultural industry and the spread of the national image, taking active measures to support the cultural trade. One of the key problems is the issue of copyright protection, which is even more difficult and important in the context of internet environment. The protection of intellectual property rights is an inevitable problem in the development of the cultural industry. For thousands of years, China did not have the concept of intellectual property rights, and intellectual property protection awareness is not strong in people's mind. However, to the situation of nowadays, if intellectual property rights are not protected properly, it will become a restrictive factor for the development of the knowledge economy. Besides protecting the intellectual property rights of foreign works which is published in China, as the Chinese culture going global, the government should also pay more attention to protect the intellectual property rights of Chinese products abroad. The Opinions of the State Council on Accelerating the Development of International Cultural Trade proposes that by 2020, a group of export-oriented cultural enterprises with international competitiveness will be cultivated to explore the international market, with the spread of China's good image and core value. Judging from the present situation, this goal still has a long way to go.

\section{CONCLUSION}

In short, international cultural trade can unleash a kind of daily strengthening power of the value and image of one country. When national or cultural identity is viewed as a vision of the future, rather than a tradition, the relationship among China and other countries may be more plastic, and leaving enough room for dialogue and negotiation for mutual consensus.

In addition, when we talk about cultural trade, we do not only focus on the export of Chinese cultural products and services, but also focus on cultural products imports, absorbing advanced experience from other countries and buying high-quality cultural products and services to meet the cultural needs of Chinese people. People around the world have cultivated and created unique traditions and cultures, which together constitute the colourful human civilization of the world. As a flourishing big country, China has showed its respect to the traditions and cultures of various countries and nations. In this kind of mutual trades, it will form sufficient competition in the interaction and help to shape and spread China's national image.

\section{ACKNOWLEDGMENT}

This work was supported by one of the key projects of the National social Science Fund of China (NO.17AZD035), whose name is Study on the Evaluation of the Effect of Chinese Culture Going Global.

\section{REFERENCES}

[1] Tomlinson, J. (2002) Globalization and culture. Nanjing University Press, Nanjing.

[2] Yang L, (2009) Research on the Going Global Strategy of Chinese Culture in Recent Years. Explore, 51-59.

[3] Li H. (2015) International Cultural Market Report. Capital University of Economics and Business Press, Beijing.

[4] UNESCO. (2002) World Culture Report. Peking University Press, Beijing.

[5] Miao R. (2013) Reflection and Reference: The Realistic Enlightenment of American Public Cultural Policy on the Sharing of China's Cultural Development Results, Academic Forum, 56.

[6] Li H. (2015) International Cultural Market Report. Capital University of Economics and Business Press, Beijing.

[7] Gong Y, Guan K. (2016) Culture Goes Out, People's Daily, November 23, 2016, 12th edition. 